\title{
SYMPTOMS OF WATER EUTROPHICATION IN THE BACHMATY RESERVOIR
}

\author{
Anna Siemieniuk', Joanna Szczykowska', Józefa Wiater ${ }^{1}$ \\ 1 Faculty of Civil and Environmental Engineering, Bialystok University of Technology, Wiejska St. 45d, 15-351 \\ Białystok, Poland, e-mail: a.siemieniuk@pb.edu.pl; j.szczykowska@pb.edu.pl; j.wiater@pb.edu.pl
}

Received: 2015.06 .16

Accepted: 2015.08.31

Published: 2015.10.01

\begin{abstract}
When analyzing the symptoms of eutrophication and water quality in a small retention reservoir Bachmaty, an attempt to assess changes in its trophic condition before and after modernization, was undertaken. The study upon changes in water trophic level was carried out on a small retention reservoir Bachmaty located in Podlasie region on the Orlanka river in the municipality of Dubicze Cerkiewne. Tests of water samples collected from the surface layer of the coastal zone were performed once a month, and the time of the research was divided into two periods. The first period was conducted since April 2007 to March 2008 and since April 2009 to March 2010. The second research period included the time immediately after the reservoir reclamation, which ended in May 2011. The study was conducted since May 2011 to March 2012 and since April 2013 to March 2014. The trophic level of Bachmaty reservoir was also assessed according to the concentration criteria and based on the trophic status indices (TSI) calculated after Carlson's as well as Kratzer and Brezonik's. Reclamation of the reservoir, which consisted mainly in removing the sediments, caused a reduction in all TSI values. Analysing the overall trophic level index, i.e. the average of TSI (TP), TSI (TN), and TSI (Chl), water of the Bachmaty reservoir may be classified as eutrophic in individual years of the research, although a gradual decline in the TSI value could be observed directly after the reservoir modernizing. After testing it was found that the formation of the trophic level of Bachmaty reservoir was largely affected by the amount of total phosphorus supplied to the water. Water quality in the reservoirs, and also the content of phosphorus compounds is largely determined by external supply.
\end{abstract}

Keywords: small retention reservoir, contaminants, biogenic compounds, trophic level

\section{INTRODUCTION}

Small retention is the accumulation of water in small reservoirs by stopping or slowing the water run-off, while maintaining the natural landscape. This applies mainly to small objects of local significance and impact. Most of these bodies receive contaminants delivered primarily through water courses from mostly agricultural areas. These reservoirs have different surface areas, are usually shallow, and thermally not-stratified for greater part of the year.

A process that mainly threatens the water of small retention reservoirs, is eutrophication, which affects the quality of their water. The most spectacular manifestation of eutrophication are blooms of water, caused by increased growth of vegetation. The plant production is affected by many factors: light, temperature, nutrient levels, as well as morphological, hydrodynamic, and hydro-biological properties of waterways and reservoirs. However, the factors necessary for the development of aquatic vegetation are biogenic elements. These include hydrogen, carbon, nitrogen, oxygen, phosphorus, sulphur, sodium, magnesium, potassium, calcium, iron, manganese, zinc and tin [1]. Eutrophication processes are accelerated as a result of draining the excessive amounts of nitrogen and phosphorus to the surface water from anthropogenic sources. The sources of nitrogen and phosphorus as well as other components are primarily the large-scale used organic fertilizers, such as liquid and solid manure and also mineral fertilizers. One of the 
most dangerous sources biogenic substances supply to the waters is municipal wastewater, both treated and untreated $[2,3]$. Eutrophication process is stimulated by phosphorus compounds present in municipal wastewater, which are derived from detergents.

The most visible effect of eutrophication is increased turbidity of water. It primarily depends on the presence of various insoluble inorganic or organic compounds of natural and anthropogenic origin, such as particles of rocks and soils, iron, manganese, calcium and phosphorus compounds, humic substances, plankton, higher microorganisms [4].

Eutrophication leads to a significant deterioration in the performance of water, especially in terms of organoleptic indicators, such as smell, taste, colour, turbidity [5]. One of the methods to improve the quality of water in small reservoirs is their modernization.

Analyzing the symptoms of eutrophication and water quality in small retention Bachmaty reservoir, an attempt to identify changes in its trophic level before and after modernization, was undertaken.

\section{METHODS}

Studies of the trophic level changes in water and its quality were carried out in small retention reservoir Bachmaty located in the Podlasie region on the river Orlanka in the municipality of Dubicze Cerkiewne. The Bachmaty reservoir was built on the $44+795 \mathrm{~km}$ of the river Orlanka in 1985 by water damming with earthen dam. The area of the reservoir is 5.5 ha and volume of accumulated water is $75000 \mathrm{~m}^{3}$. Hydrological catchment of the reservoir occupies the area of $22.8 \mathrm{~km}^{2}$, its width is $60-90 \mathrm{~m}$, and length $760 \mathrm{~m}$. Normal storage level (NPP) reaches the height of $3.25 \mathrm{~m}$, and mean depth at NPP is $1.5 \mathrm{~m}$. The reservoir is supplied with water from the river Orlanka, rainwater, and from the surface runoff [6].

The priority task of Bachmaty reservoir is water retention which helps maintain the stability of the natural environment. Accumulated water increases the water capacity of soils on surrounding areas. The reservoir also fulfills the functions of flood control, environmental protection, extensive fish farming (every year the reservoir is stocked with precious species of fish), and increased value of rural landscape, as well as rest and recreation. Bachmaty reservoir is located on an almost flat plain. In this area, there are only slight hills, and the reservoir is an element enriching the existing natural landscape. Wooded areas are situated near the reservoir. Surrounding the reservoir is a recreational area with sandy beaches, next to which there are accommodation places with cottages and campsites. There is also a swimming equipment rental, e.g. water-bicycles or canoes [6]. Further of the reservoir, there are agricultural areas used for grassland, meadows, and pastures. The long life of exploitation led to silting the bottom of the reservoir and the river. This contributed to the deterioration of reservoir water quality and environmental imbalance. The shallowness and the presence of cyanobacteria was associated with the need to limit the use of the reservoir for recreational purposes. This contributed to a reduction in the landscape value of the area and reduction in the number of tourists [6]. In order to maintain the good condition of the reservoir, as well as the environmental sustainability, it was modernized in 2011. The reclamation works included, among others, draining the water from the reservoir, de-silting the bottom of the river, and cleaning the damming buildings. General modernization of the Bachmaty reservoir was completed on May 26, 2011.

In order to assess the quality of reservoir water, three measurement and control points were selected, which were situated within the inflow (point No 1) and outflow (point No 3) to the river Orlanka, as well as in the central part of the reservoir (point No 2). The selection and placement of measurement and control points in the reservoir was dictated by the ability to capture the changes occurring in the object under study. The collected waters were subject to determine the following items: total nitrogen, total phosphorus, chlorophyll "a", and turbidity. Tests of water samples collected from the surface layer of the coastal zone, were carried out once a month, and the time of the research was divided into two periods. The first period was conducted since April 2007 to March 2008 and since April 2009 to March 2010. The second research period included the time immediately after the reservoir reclamation, which ended in May 2011. The study was conducted since May 2011 to March 2012 and since April 2013 to March 2014. All the tests were performed in accordance with the current methodology [7].

The level of significance and power of the test assumed in the calculations as a measure of the 
Table 1. The results of the power of the tests in the Bachmaty reservoir

\begin{tabular}{|l|c|c|c|c|}
\hline \multicolumn{4}{|c|}{ Bachmaty reservoir } \\
\hline \multicolumn{1}{|c|}{ Parameters } & TN & TP & Chlorophyll & Turbidity \\
\hline The average value of the null hypothesis (Mi0) & 0,00 & 0,00 & 0,00 & 0,00 \\
\hline The average value in the population (Mi) & 2,02 & 0,43 & 3,30 & 19,14 \\
\hline Population standard deviation (Sigma) & 2,53 & 0,36 & 1,79 & 11,05 \\
\hline Standardized effect (Es) & 0,80 & 1,19 & 1,85 & 1,73 \\
\hline Probability of the I type error (Alfa) & 0,05 & 0,05 & 0,05 & 0,05 \\
\hline Target power & 0,80 & 0,80 & 0,80 & 0,80 \\
\hline The power of required numerical force of sample N & 0,82 & 0,82 & 0,86 & 0,82 \\
\hline Required numerical force of sample (N) & $\mathbf{1 5 , 0 0}$ & $\mathbf{8 , 0 0}$ & $\mathbf{5 , 0 0}$ & $\mathbf{5 , 0 0}$ \\
\hline
\end{tabular}

reliability of the test results. The procedure uses a method of mathematical statistics regarding power analysis tests. The results of calculations are given in Table 1.

The trophic level of Bachmaty reservoir was also assessed according to the concentration criteria and based on the trophic status indices (TSI) calculated after Carlson's as well as Kratzer and Brezonik's. The trophic indices were calculated according to Carlson TSI (Chl) in $\mu \mathrm{g} / \mathrm{dm}^{3}$, TSI (TP) in $\mu \mathrm{g} / \mathrm{dm}^{3}$, according to Kratzer and Brezonik TSI (TN) in $\mathrm{mg} / \mathrm{dm}^{3}$ and general trophic level of the reservoir TSI was assessed using the achieved mean value from the three calculated indices TSI(Chl), TSI(TP), TSI(TN). Water transparency measured by Secchi disc was skipped, because it is of little importance in the dam reservoirs, when assessing the trophic status. Water inflowing during the heavy rainfall supply large amounts of suspensions that cause turbidity of retained water. The reduction in water transparency due to this fact is not related to the growth of phytoplankton $[8,9]$. The values of the trophic status indicators by Carlson are as follows: TSI $<40$ oligotrophy, 40-50 mesotrophy, 50-70 eutrophy, $>70$ hypertrophy [10]. Assessment of the eutrophication degree is made on the basis of average annual values of biogenic indicators for flowing waters [11].

\section{RESULTS AND DISCUSSION}

Analyses of total nitrogen concentration in water during the research showed its remarkable variability. The mean concentration of total nitrogen before modernization of the reservoir, i.e. in 2007/2008 and 2009/2010 ranged from 2.19 to $2.42 \mathrm{mg} \mathrm{N} / \mathrm{dm}^{3}$. After reservoir cleaning, these values decreased to the average annual ones from 1.1 to $1.52 \mathrm{mg} \mathrm{N} / \mathrm{dm}^{3}$ in $2011 / 2012$ and 2013/2014 (Table 2). Factor causing such high values of total nitrogen in the water is probably the residual sludge at the bottom of the reservoir, that got into the reservoir water in the form of humic substances along with waters of the river Orlanka, the catchment of which is located in the agro-forestry area. Regardless of the date of the study, seasonal changes in this element were monitored. Lower levels of total nitrogen were recorded in the spring and summer, while higher in autumn and winter. At the same time, larger values of this element were found before reservoir reclamation.

Table 2. Results for waters from the Bachmaty reservoir before and after reclamation

\begin{tabular}{|c|c|c|c|c|c|}
\hline \multirow[t]{2}{*}{ Parameter } & \multirow[t]{2}{*}{ Unit } & \multicolumn{2}{|c|}{$\begin{array}{l}\text { Before reclamation } \\
\frac{\min -\max }{\text { average }}\end{array}$} & \multicolumn{2}{|c|}{$\begin{array}{l}\text { After reclamation } \\
\frac{\min -\max }{\text { average }}\end{array}$} \\
\hline & & IV 2007 - III 2008 & IV 2009 - III 2010 & V 2011 - III 2012 & IV 2013 - III 2014 \\
\hline Total nitrogen (TN) & $\mathrm{mg} \mathrm{N} / \mathrm{dm}^{3}$ & $\frac{0.5-10.25}{2.42}$ & $\frac{0.59-8.33}{2.19}$ & $\frac{0.1-4.38}{1.1}$ & $\frac{0.1-3.98}{1.52}$ \\
\hline Total phosphorus (TP) & $\mathrm{mg} \mathrm{P} / \mathrm{dm}^{3}$ & $\frac{0.29-1.36}{0.64}$ & $\frac{0.36-1.46}{0.67}$ & $\frac{0.01-1.56}{0.25}$ & $\frac{0.06-0.23}{0.13}$ \\
\hline Chlorophyll „a” & $\mu \mathrm{g} / \mathrm{dm}^{3}$ & $\frac{1.96-6.07}{3.89}$ & $\frac{2.27-7.15}{4.61}$ & $\frac{1.02-3.21}{2.09}$ & $\frac{0.98-4.54}{2.51}$ \\
\hline Turbidity & NTU & $\frac{20-36}{28.08}$ & $\frac{20-39}{29.42}$ & $\frac{2-10}{6.64}$ & $\frac{8-15}{11.42}$ \\
\hline
\end{tabular}


Similar trends were observed for certain concentrations of the total phosphorus, the values of which before modernization of the reservoir ranged from 0.64 to $0.67 \mathrm{mg} \mathrm{P} / \mathrm{dm}^{3}$. Penetration of phosphorus from bottom sediments into the water is a problem that significantly complicates the reclamation treatments in reservoirs, especially small and shallow ones [12]. Retention of phosphorus in bottom sediments includes three main processes: deposition on sediments, transformation of organic phosphorus and its restraining and hiding in sediments or movement of phosphorus to the deeper layers. If the deposition is faster than the other two processes - then the excess of phosphorus remaining in constant contact with the water of the reservoir is observed. In this case, sediment becomes an important internal source of phosphorus and maintains the eutrophication process, even after the reduction of external phosphorus sources $[12,13]$. The average concentration of the biogenic agent determined after cleaning the reservoir is smaller and amounts to $0.13-0.23 \mathrm{mg} \mathrm{P} / \mathrm{dm}^{3}$. Also in this case, its seasonal occurrence was observed. Like in the case of the total nitrogen, the lowest concentrations of phosphorus were recorded during the spring and summer, whilst higher in the autumn-winter season. The high content of total phosphorus can be affected by re-suspending the sediments deposited on the bottom of the reservoir, which were produced, among others, as a result of the surface runoff and contaminants sedimentation. Water, during the contact with the soil surface, dissolves phosphates contained therein and lifts light and loose material in a form of plant residues, residues of natural and mineral fertilizers [14]. The first stage of the surface runoff is dissolution, desorption, and extraction of phosphorus compounds from the soil by rainwater, and the second - actual transport [15]. Despite of the small phosphorus migration within the soil, its content in surface waters can be quite substantial.

The tests of chlorophyll "a" in waters of the Bachmaty reservoir, regardless of the time of study, revealed seasonal fluctuations in its content. Increased concentrations of chlorophyll "a" were determined in spring, summer and autumn, while its levels were reduced in winter reaching the minimum. The average concentration of chlorophyll "a" in water of Bachmaty reservoir ranged from 3.89 to $4.61 \mu \mathrm{g} / \mathrm{dm}^{3}$ during the study before reservoir reclamation, while after modernization - from 2.51 to $2.59 \mu \mathrm{g} / \mathrm{dm}^{3}$.
The analyses showed a considerable variation in water turbidity values in individual years of the research. Before works associated with the reservoir de-silting, the annual average turbidity value ranged 28.08-29.42 NTU, while after reservoir reclamation, it decreased to 7.83-11.42 NTU. There were no seasonal incidence of turbidity. The change in this parameter could be influenced by many factors dependent on both technological and structural conditions of the reservoir. These include, among others, time of water retaining in reservoir, frequency and extent of fluctuations in water level, season and weather conditions, condition of the reservoir bottom and walls being in contact with water, method of reservoir operation, water flow through the reservoir ensuring perfect mixing and full exchange, as well as the depth of water in the reservoir [16].

The study revealed that the average TSI (TP) in 2007/2008 and 2009/2010 ranged within 96.88-97.31, allowing to classify the reservoir as hypertrophic (Figure 1). Despite of a significant decline in the TSI (TP) after reservoir modernization, determined values of 73.04-75.71 still qualify it as hypertrophic. Average annual TSI (TN) prior to reclamation was within 63.06-64.89 qualifying the reservoir to eutrophic (Figure 2). After the reclamation of reservoir, the trophy level indicator decreased to $46.4-57.59$ borders indicating that the water in the first year was mesotrophic, and as early as the following research year - eutrophic. When determining the trophic status based on the content of chlorophyll "a", water in the Bachmaty reservoir was classified as mesotrophic and oligotrophic. The average annual TSI (Chl) was in the range 42.94-44.75 during the research before reclamation and 37.16-38.54 after the removal of silt (Figure 3).

Comparing the analyses made in 2007/2008 and 2009/2010, a slight, although increasing trend in average trophic levels, was observed. Reclamation of the reservoir, which consisted mainly in removing the sediments, caused a reduction in all TSI values. Analyzing the overall trophic index, i.e. the average of TSI (TP), TSI (TN), and TSI (Chl) (Figure 4), water of the Bachmaty reservoir in individual years of study were classified as eutrophic, although a gradual decline in the value of TSI directly after modernization of the reservoir, was recorded. It was found that formation of the trophic status of the Bachmaty reservoir was largely affected by the amount of total phosphorus supplied to its wa- 


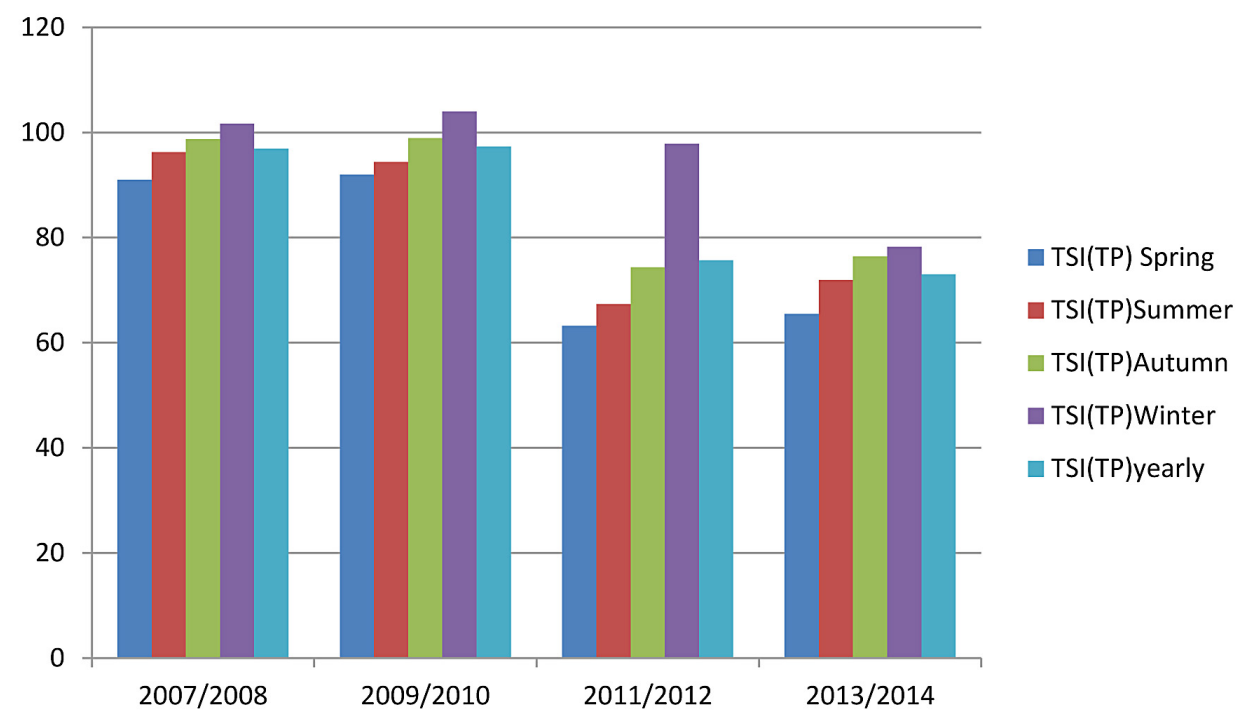

Figure 1. Average trophic level TSI(TP) of the Bachmaty reservoir in individual seasons and research years

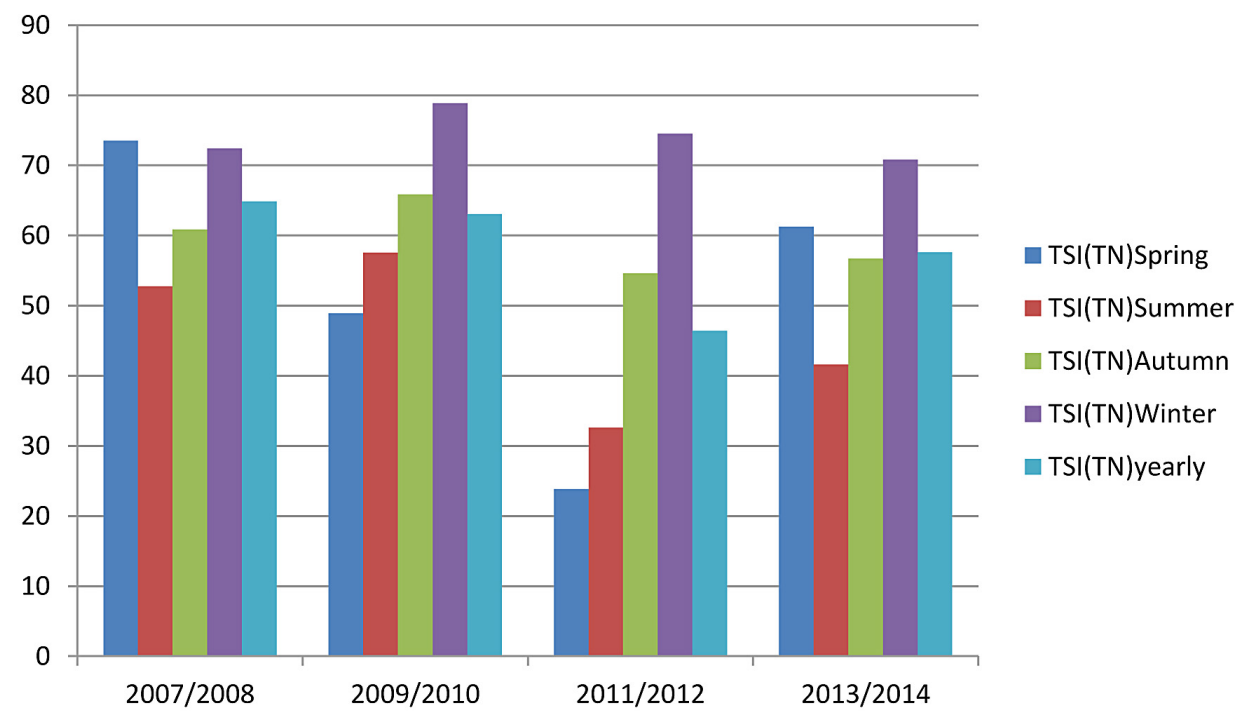

Figure 2. Average trophic level TSI(TN) of the Bachmaty reservoir in individual seasons and research years

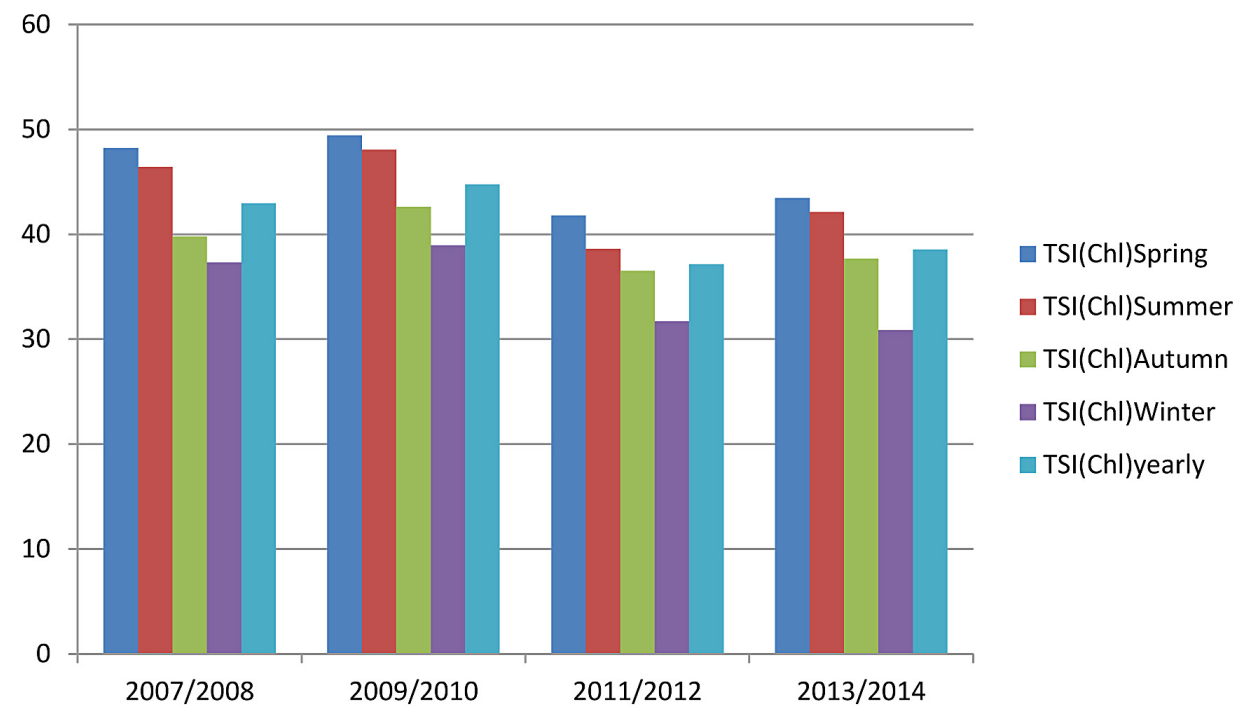

Figure 3. Average trophic level TSI $(\mathrm{Chl})$ of the Bachmaty reservoir in individual seasons and research years 


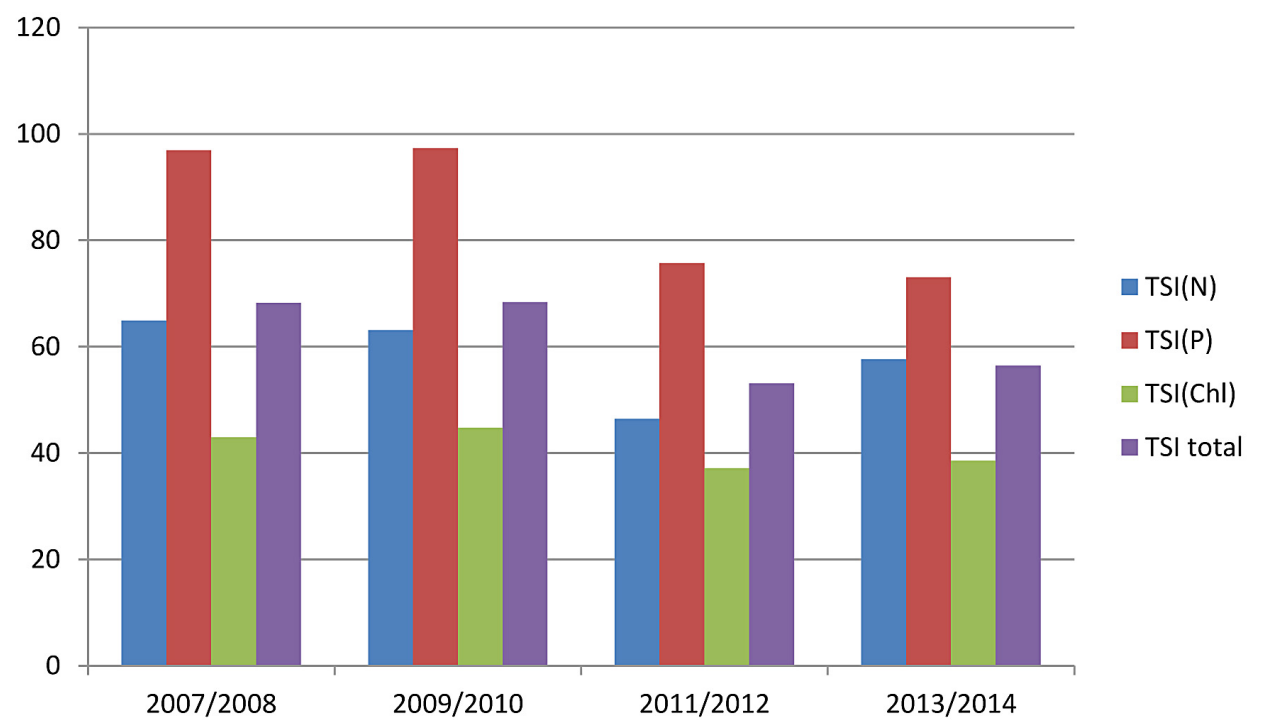

Figure 4. Annual average trophic level of the Bachmaty reservoir in individual research years

ters. The quality of water in reservoirs, mainly the concentration of phosphorus compounds, is largely determined by the external supply. Phosphorus compounds enter the water of reservoirs through different routes: with inflow of the river, rarely with the area runoff, mainly with point discharges of contaminants in wastewater, as well as from the atmosphere etc. [17]. Advanced eutrophic processes occurring in the Bachmaty reservoir occur probably due to the inflow of large amounts of humus and biogenic substances from the catchment area, because forests and agricultural areas are a large part of this area. Organic compounds flowing into the reservoir can be biodegradable and decomposed, and some of them can float in the water, while some falls at the bottom forming sediments. Long operation life of the reservoir led to its siltation and shallowing. This contributed to the deterioration of water quality in the Bachmaty reservoir, increased trophic level, and often presence of cyanobacteria. Similar situation is observed in other small retention reservoirs located in the Podlasie region, where significant percentage of river catchments that supply water to reservoirs, are the forest areas and farmlands. Supplying the water reservoirs with phosphorus and nitrogen compounds accelerates the natural aging, and in extreme cases, rapid degradation [18].

\section{CONCLUSIONS}

1. Reclamation of the reservoir caused reduction in nitrogen and phosphorus concentration in water by more than $50 \%$ and significant reduction in turbidity.

2. The concentration of biogenic substances in water was subject to seasonal variations, and in the case of water turbidity, such dependence was not confirmed.

3. Due to the index of the overall trophic level, water in the Bachmaty reservoir during the years of study was classified as eutrophic, even though there was a decrease in TSI value immediately after reservoir modernization.

4. The trophic status of the reservoir water is determined mainly by the supply of phosphorus from external sources and as a result of its mobilization from bottom sediments.

\section{REFERENCES}

1. Bartsch A.F. 1972. Role of phosphorus in eutrofication. EPA-R3-1972.

2. Boers P.C.M., Van Raaphorst W., Van der Molen D.T. 1998. Phosphorus retention in sediments, Wat. Sci. Tech. 37, 3, 31-39.

3. Bootsma M.C., Barendregt A., van Alphen J.C.A. 1999. Effectiveness of reducing external nutrient load entering a eutrophicated shallow lake ecosystem in the Naardermeer nature reserve. The Netherlands, Biological Conservation 90, 193-201.

4. Carlson R.E. 1977. A tropic state index for lakes. Limnology and Oceanography, 22.

5. Cheng W.P., Chi F.H. 2003. Influence of eutrophication on the coagulation efficiency in reservoir water. Chemosphere, 53(7), 773-778. 
6. Czaplicka-Kotas A., Ślusarczyk Z., Pięta M., Szostak A. 2012. Analiza zależności między wskaźnikami jakości wody w Jeziorze Goczałkowickim w aspekcie zakwitów fitoplanktonu. Ochrona Środowiska, 1 (34), 21-27.

7. Durkowski T. 1997. Zasoby wodne a jakość wody w rolnictwie. Zeszyty Edukacyjne IMUZ Falrnty, 3/97, 17-38.

8. Europejska Agencja Środowiska 2010. Freshwater Eutrophication Assessment. ETC Water Technical Report 2.

9. Hermanowicz W. et al. 1999. Fizyczno-chemiczne badanie wody i ścieków. Wydawnictwo Arkady, Warszawa.

10. Komisja Europejska 2006. Sewage effluent phosphorus - a major risk to river eutrophication.

11. Niepublikowane materiały udostępnione przez gminę Dubicze Cerkiewne.

12. Pawełek J. 2000. Zmiana mętności wody ujmowanej z Rudawy dla potrzeb Krakowa poprzez zastosowanie zbiorników zapasowych. IX Krajowa, II Międzynarodowa Konferencja NaukowoTechniczna, Zakopane-Kościelisko.
13. Dz.U. 2002 nr 241, poz. 2093. Rozporządzenie Ministra Środowiska z dnia 23 grudnia 2002 r. w sprawie kryteriów wyznaczania wód wrażliwych na zanieczyszczenia związkami azotu ze źródeł rolniczych.

14. Steineck S., Jakobsson Ch., Carlson G. 2002. Fosfor - stosowanie, wykorzystanie przez rośliny uprawne i nagromadzenie w glebach użytków rolnych. In: B. Sapek (Ed.) Rolnictwo polskie i ochrona jakości wody - monografie. Zeszyty Edukacyjne IMUZ Falenty, 7, 25-37.

15. Szczykowska J., Siemieniuk A., Wiater J. 2013. Problemy ekologiczne zbiorników małej retencji na Podlasiu. Ekonomia i Środowisko, 4, 234-244.

16. Szczykowska J., Siemieniuk A., Wiater J. 2013. Sezonowe zmiany stanu troficznego zbiorników retencyjnych. Ekonomia i Środowisko, 2, 107-116.

17. Wajner J. 2006. Życie i ewolucja biosfery. PWN Warszawa.

18. Wiśniewski R.J. 1995. Rola zasilania wewnętrznego w eutrofizacji zbiorników zaporowych. [In:] M. Zalewski (Ed.) Procesy biologiczne w ochronie i rekultywacji nizinnych zbiorników zaporowych. Biblioteka Monitoringu Środowiska, Łódź, 61-70. 